\title{
Barbara Cavasso and Guglielmo Weber \\ 3 The effect of the great recession on the wealth and financial distress of 65+ Europeans
}

- Household wealth plays a key role in smoothing out adverse shocks for retirees

- Many older households have little (liquid) wealth, especially in Southern and Eastern European countries

- Financial distress has increased with the crisis

- Pre-crisis high income, home-ownership, education and being married reduce the risk of falling into financial distress

\subsection{The financial crisis and low wealth among Europeans past retirement age}

The key theoretical model used by economists to understand individual consumption and saving behaviour is Franco Modigliani's life cycle theory (Modigliani \& Brumberg 1954; Modigliani 1976). According to this theory, forward-looking consumers aim at keeping the same living standard over time, and to this end accumulate real and financial assets during their working lives, and use up the wealth they have so accumulated during their retirement years. Wealth plays a crucial role in supporting consumption in old age, particularly for those individuals whose retirement income falls below their pre-retirement earnings. The more liquid part of wealth, financial wealth, is likely to be used up first in times of need - an adverse health shock, or an unexpected reduction in income, should lead to a reduction in financial wealth.

This chapter investigates how wealth holdings of the European individuals past retirement age (aged 65 or more) were affected by the onset of the great recession, and in particular to what extent the adverse business cycle conditions have increased their financial distress (an indicator defined similarly to the one proposed in a recent paper by Christelis et al. 2009).

After a brief review of the key concepts, based on Wave 4 data (that cover four new countries, two of which most heavily affected by the recession: Portugal and Hungary), we display changes for those individuals who participated in both Waves 2 and 4 (Wave 3 does not record wealth holdings). The resulting sample 
(of 65+ as of 2006) is relatively small and includes only twelve countries, but the analysis captures business cycle effects, as the first wave we consider was before the great recession (2006-7), whereas the second wave (2010-11) was well after it.

\subsection{A snap-shot of Europe during the crisis}

We know from a number of papers (Angelini et al. 2012) that housing wealth plays a key role in household portfolios.

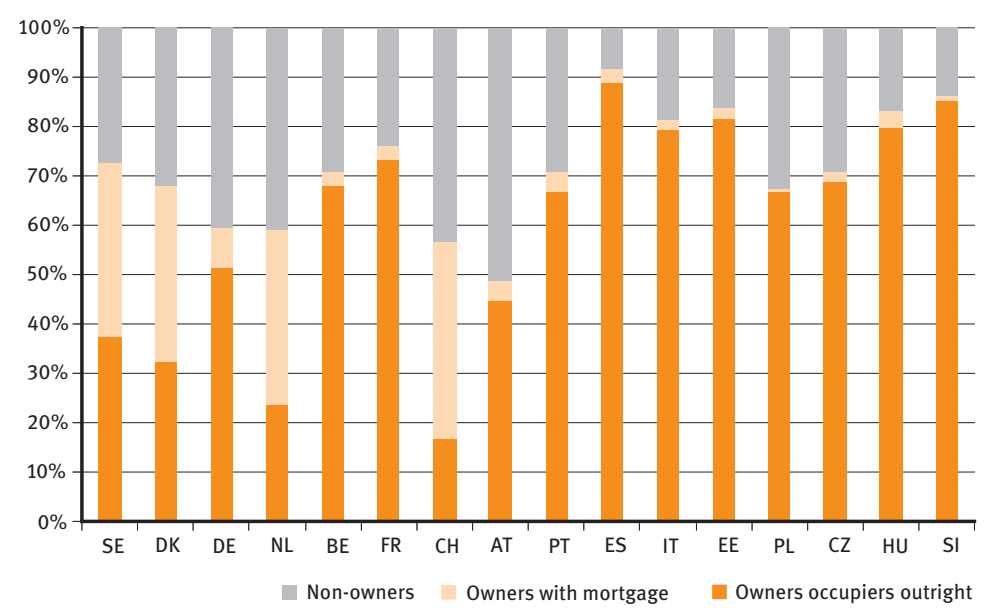

Figure 3.1: Housing tenure by country

Notes: 21,102 observations

Source: SHARE Wave 4 release 1

Figure 3.1 shows housing tenure choice in all Wave 4 countries. Home-ownership rates are high in Austria, Switzerland, Germany and the Netherlands, very high (above 60\%) in all other countries. Mortgages are relatively common in only four countries (Sweden, Denmark, the Netherlands and Switzerland), rare or extremely rare in all other countries (including Portugal, Hungary, Slovenia, Estonia and Poland). The largest proportions of home-owners without a mortgage ("outright") are observed in Southern countries (especially Spain) and in Eastern countries. Note that in this paper non-home-owners include tenants and people living in rent-free accommodation, as well as nursing home residents (who are overall only $1.64 \%$ of our sample, due to the selection rules adopted by SHARE). 


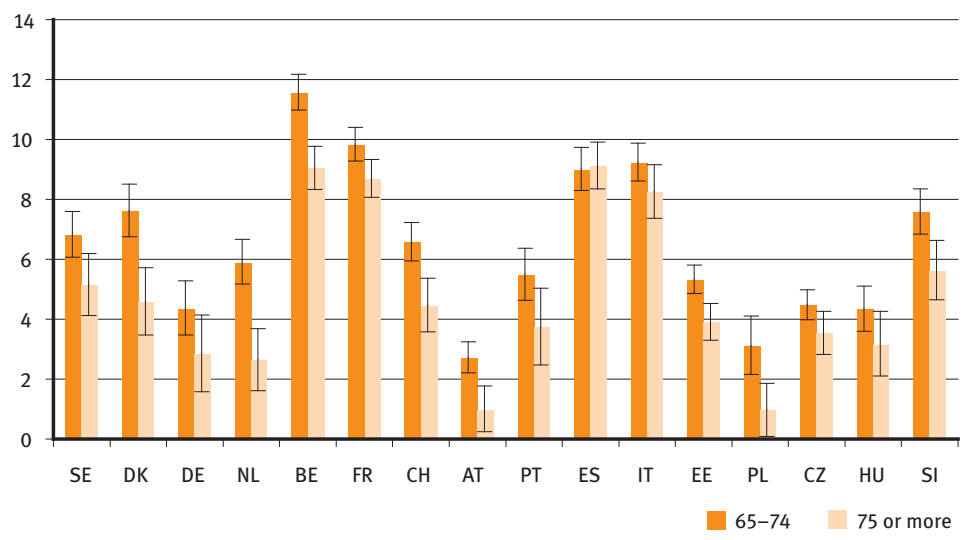

Figure 3.2: Net worth income ratio by age Notes: 21,102 observations

Source: SHARE Wave 4 release 1

Figure 3.2 displays the median ratios of net worth to income by age band: households are classified according to the age of the financial respondents in a younger group (65-74) and in an older group (75+). Household net worth is defined as the sum of all real and financial assets, minus liabilities. The real assets value is the sum of the market values of the main residence, of other real estate, own business and cars, minus the outstanding mortgage on the main residence. The financial assets value is the sum of the balance in bank accounts, government and corporate bonds, stocks/shares, mutual funds, individual retirement accounts, contractual savings for housing and the face value of life insurance, net of liabilities (that include all non-mortgage debt). Household income is defined as the total income received by all household members, net of taxes and contributions.

A high value of the ratio denotes the presence of an adequate buffer of wealth in case of need. It could also imply very low income, but in all European countries the older people qualify for some form of pension income, so this is a less likely case. The picture reflects a lot home-ownership patterns both across countries and between age groups (the older are more often non-owners in Germany, the Netherlands and Austria, partly because of public housing accommodation available to individuals of the pre-war generations, partly as a result of testamentary rules, whereby the surviving spouse does not inherit the place of residence, rather acquires the right to live there for free for the rest of her life).

This figure suggests net worth is not necessarily the most interesting concept to use if one is concerned with potential financial distress, also known as financial 
fragility. In particular, Christelis et al. (2009) argue for a measure that is based on the financial wealth income ratio: if financial wealth, net of non-mortgage debt, is less than three months' income there is a risk of financial distress in case of need. This indicator is still biased as an individual with a high income can appear as financially distressed only because he has a relatively low level of financial wealth. We adjust the indicator of financial distress to account for this situation. The indicator of financial distress we compute considers distressed individuals whose financial wealth (value of net financial assets) is lower than three months of income and whose per-capita income is not in the top third of the income distribution (we also experimented with a per-equivalent adult income concept, as in the chapter by Adena and Myck in this volume, obtaining similar results).

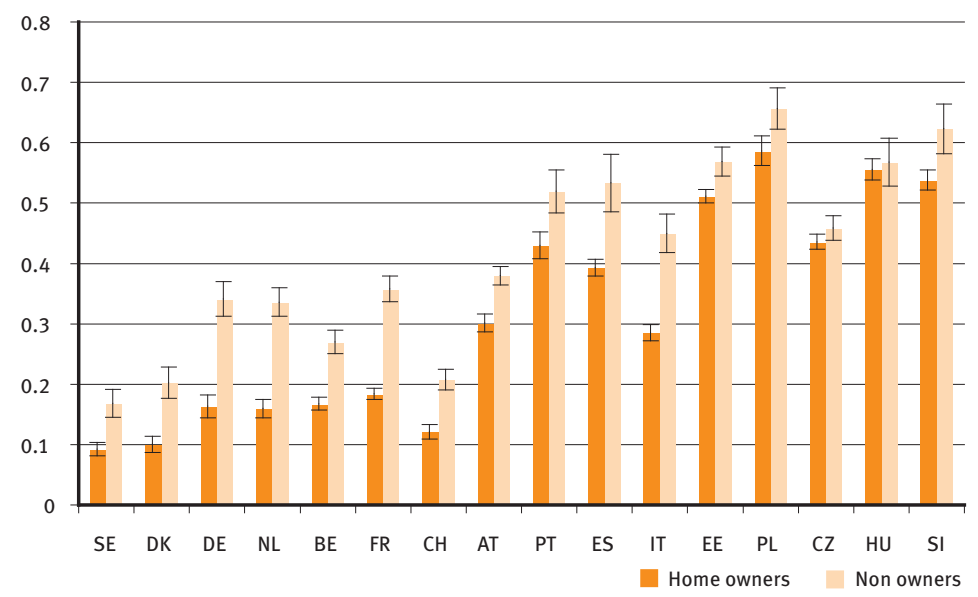

Figure 3.3: Fraction of households in financial distress

Notes: 21,102 observations

Source: SHARE Wave 4 release 1

Figure 3.3 reveals that financial distress is particularly high among tenants (who are on average poorer in all countries). It also reveals dramatic differences across countries: financial distress is particularly low among home-owners in Sweden and Denmark - highest among home-owners in Slovenia, Hungary and Poland. Among renters, it is above 50 per cent in Estonia, Slovenia and Poland, above 40 per cent also in Portugal, Spain, Italy, the Czech Republic, and Hungary. 


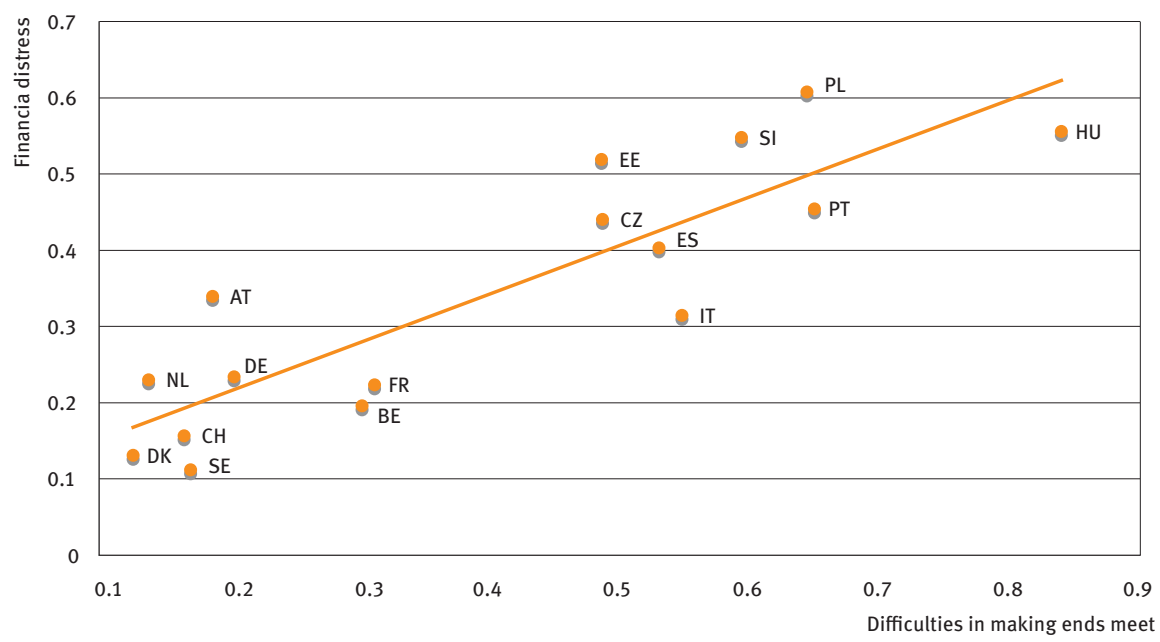

Figure 3.4: Households with a low wealth-income ratio versus difficulties making end meet Notes: 21,102 observations

Source: SHARE Wave 4 release 1

In Figure 3.4 we compare our measure of financial distress with a widely used indicator of financial hardship: the proportion of households who report difficulties making ends meet. We see that there is a strong positive correlation, but with some clustering along regional/language dimensions (Nordic and Germanic countries to the left, French in the middle, Latin and Slavic countries to the right). Hungary is instead an outlier, with well over 80 per cent of respondents reporting difficulties making ends meet, but a more moderate distress index of 50 per cent. It is well known that Hungary was hard hit by the great recession and this may have an impact on the reporting style to the more subjective questions on making ends meet.

We estimated a probit model for financial distress as a function of demographics (gender, marital status and age; education), health (self-reported poor or very poor health; presence of limitations in ADL), home-ownership and (the logarithm of per-capita) income, to assess to what extent an increase in income could reduce the risk of financial distress. Our estimates (reported in Table 3.1) show that education has a highly protective role, and so do home-ownership and income. A one percentage increase in per-capita income reduces the probability of financial distress by 4.6 per cent; the probability that a home-owner is in financial distress is 5.4 per cent lower than it is for tenants. 
Table 3.1: Probit estimates for financial distress

\begin{tabular}{|c|c|c|}
\hline \multirow[t]{2}{*}{ Variables } & \multicolumn{2}{|c|}{ Marginal Effect } \\
\hline & Coefficients & Standard error \\
\hline Age & $0.0413^{\star \star \star}$ & $(0.009)$ \\
\hline Age squared & $-0.0003^{* * *}$ & $(0.000)$ \\
\hline Female & $0.0489^{\star \star \star}$ & $(0.007)$ \\
\hline Married & $-0.0401^{\star \star \star}$ & $(0.007)$ \\
\hline High School & $-0.1002^{\star \star \star}$ & $(0.007)$ \\
\hline College & $-0.1951^{\star \star \star}$ & $(0.007)$ \\
\hline Logarithm of per-capita income & $-0.0482^{\star \star \star}$ & $(0.002)$ \\
\hline Home-owners & $-0.0524^{\star \star \star}$ & $(0.008)$ \\
\hline Poor health & $0.0600^{\star \star \star}$ & $(0.010)$ \\
\hline Limitation with activities & $0.0477^{\star \star \star}$ & $(0.007)$ \\
\hline Sweden & $-0.1306^{\star \star \star}$ & $(0.016)$ \\
\hline Denmark & $-0.0776^{\star \star \star}$ & $(0.020)$ \\
\hline Germany & $0.0469^{\star \star}$ & $(0.024)$ \\
\hline Netherland & 0.0067 & $(0.019)$ \\
\hline Belgium & $-0.0430^{\star \star *}$ & $(0.015)$ \\
\hline Switzerland & $-0.0415^{\star \star}$ & $(0.018)$ \\
\hline Austria & $0.1321^{\star \star \star}$ & $(0.017)$ \\
\hline Portugal & $0.1881^{\star \star \star}$ & $(0.024)$ \\
\hline Spain & $0.1212^{\star \star \star}$ & $(0.019)$ \\
\hline Italy & $0.0633^{\star \star \star}$ & $(0.018)$ \\
\hline Czech Republic & $0.2120^{\star \star \star}$ & $(0.017)$ \\
\hline Hungary & $0.2671^{\star \star \star}$ & $(0.021)$ \\
\hline Slovenia & $0.3329 * \star \star$ & $(0.020)$ \\
\hline Estonia & $0.2492^{\star \star \star}$ & $(0.016)$ \\
\hline Poland & $0.3113^{\star \star \star}$ & $(0.024)$ \\
\hline N. Obs. & 21,106 & \\
\hline Pseudo R-squared & 0.1284 & \\
\hline
\end{tabular}

Significance: ${ }^{* \star *}=1 \% ;{ }^{* \star}=5 \% ;{ }^{*}=10 \%$

Notes: The dependent variable is the financial distress indicator.

Source: SHARE Wave 4 release 1 


\subsection{Financial distress and the crisis}

In this section we display the same set of indicators for those households who participated also in a previous wave. This restricts the number of countries to just twelve and the number of households in each country, both because the age limit (65+) is applied at a much earlier date (2006-7 instead of 2010-11) and because of attrition across waves (due to death or unwillingness to participate). The resulting sample size is around seven thousands households.

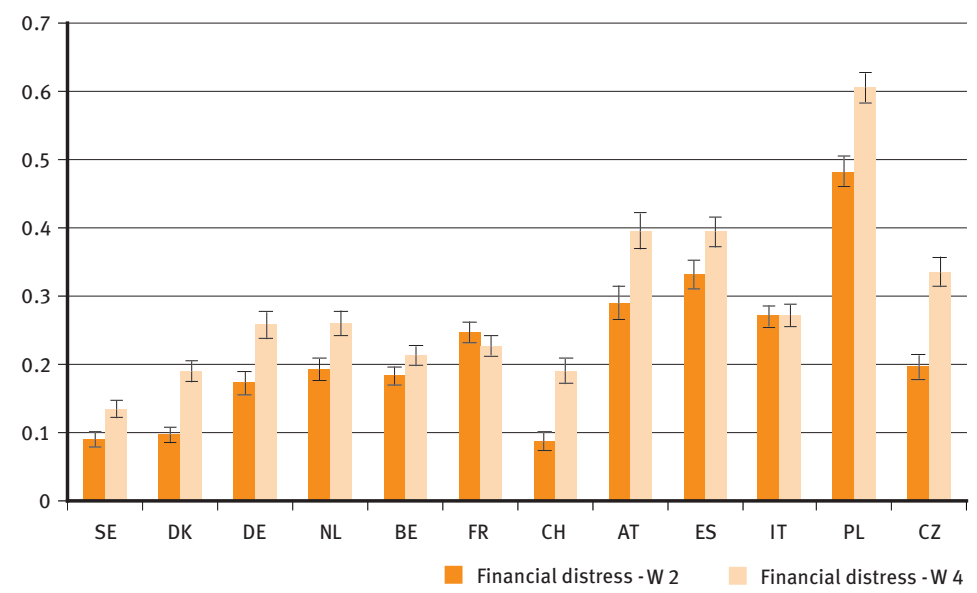

Figure 3.5: Proportions in financial distress by wave and country Notes: 7,074 observations

Source: SHARE Wave 2 release 2.5.0, Wave 4 release 1

In Figure 3.5 we show the proportions of households in financial distress, using the indicator we discussed above. It is worth noting that its changes over time are most likely driven by changes in net financial wealth, given that the incomes of the older individuals are relatively stable in real terms (pension income is typically price-indexed). To avoid spurious effects due to changes in the income cutoff, we applied the Wave 2 thresholds to both waves. Financial distress changes between Waves 2 and 4: in most countries it increases, particularly in Denmark, Switzerland, Austria, Poland and the Czech Republic. A decrease is observed in France, while there is no change in Italy (where the crisis was mostly felt after the sampling period - that ended in June 2011). In some countries (Spain and Germany) the increase in financial distress corresponds to an increase in the fraction of households who make use of non-mortgage debt. Our evidence on the effect of the great recession on the lives of European senior citizens is broadly in 
line with (but more clear-cut than) what we observe when looking at consumption-based indicators of financial hardship, that are presented in another chapter (see Angelini et al. in this volume).

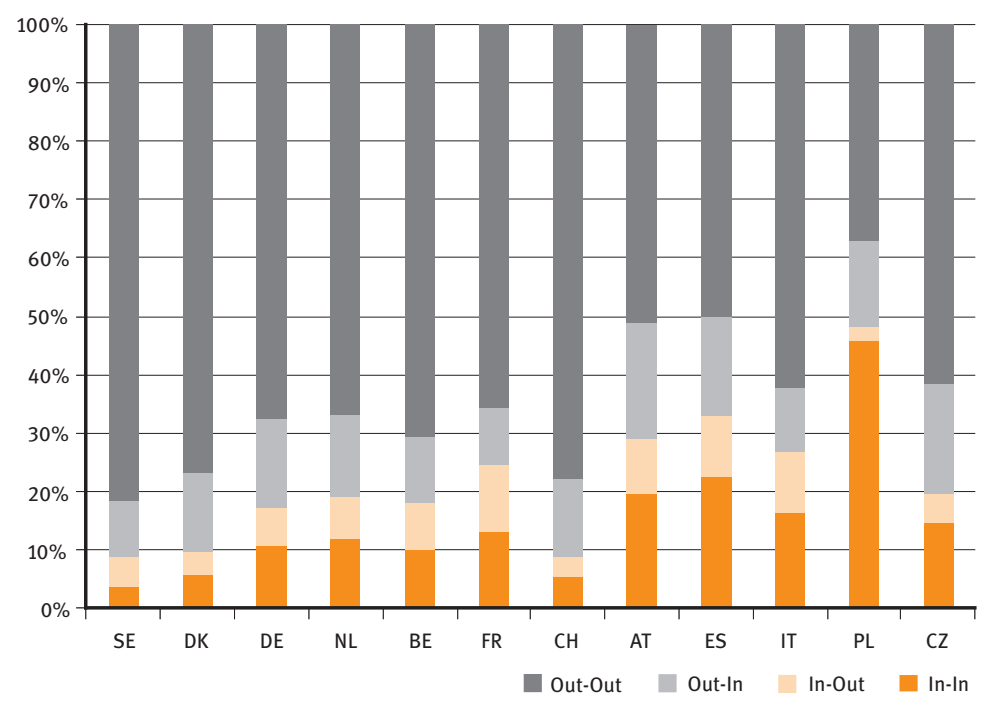

Figure 3.6: Financial distress - Transitions

Notes: 7,074 observations

Source: SHARE Wave 2 release 2.5.0, Wave 4 release 1

In Figure 3.6 we show the transition probabilities of the financial distress indicator we discussed above. We observe a lot of persistence in financial distress in Poland, Austria, Spain, the Czech Republic and Italy. Transitions into financial distress prevail in all countries but France, in agreement with what we showed in Figure 3.5. There are non-negligible fractions of households leaving financial distress in France, Italy and Spain.

We can estimate transition probabilities in and out of financial distress as a function of demographics, health, home-ownership and household income, and their changes. The effects of the recession could partly be attributed to changes in observable variables - partly to changes in coefficients. The outcome variable in the model reported in the first two columns of Table 3.2 is the probability of entering financial distress in Wave 4 given that an individual was not in financial distress in Wave 2. We estimate a protective role for Wave 2 per-capita income and homeownership, and also for education and being married, in line with what we found looking at the cross-section. Health in Wave 2, age and gender are now insignificant. 
Table 3.2: Probit estimates for transition probabilities in and out of financial distress.

\begin{tabular}{|c|c|c|c|c|}
\hline Variables & IN & & OUT & \\
\hline & Coefficients & $\begin{array}{l}\text { Standard } \\
\text { error }\end{array}$ & Coefficients & $\begin{array}{l}\text { Standard } \\
\text { error }\end{array}$ \\
\hline Age & -0.0044 & $(0.008)$ & 0.0019 & $(0.031)$ \\
\hline Age squared & 0.0003 & $(0.000)$ & 0.0000 & $(0.000)$ \\
\hline Female & 0.0069 & $(0.008)$ & -0.0623 & $(0.032)$ \\
\hline Married & $-0.0489^{\star \star \star}$ & $(0.009)$ & $0.1220^{\star \star}$ & $(0.033)$ \\
\hline High School & $-0.0207^{\star \star}$ & $(0.008)$ & $0.0109^{\star \star \star}$ & $(0.037)$ \\
\hline College & $-0.0491^{\star \star *}$ & $(0.009)$ & 0.0496 & $(0.060)$ \\
\hline Logarithm of per-capita income & $-0.1059^{\star * \star}$ & $(0.005)$ & $0.0835^{\star \star \star}$ & $(0.030)$ \\
\hline Home-owners & $-0.0513^{\star \star *}$ & $(0.010)$ & $0.1001^{\star \star \star}$ & $(0.030)$ \\
\hline Poor health & 0.0075 & $(0.009)$ & -0.0244 & $(0.044)$ \\
\hline Limitation with activities & 0.0009 & $(0.008)$ & $-0.0824^{\star \star}$ & $(0.030)$ \\
\hline Sweden & -0.0058 & $(0.016)$ & 0.0362 & $(0.075)$ \\
\hline Denmark & $0.0450^{\star \star}$ & $(0.021)$ & -0.0969 & $(0.065)$ \\
\hline Germany & $0.0448^{\star \star}$ & $(0.024)$ & -0.0460 & $(0.066)$ \\
\hline Netherland & 0.0093 & $(0.018)$ & $-0.1249 \star \star$ & $(0.053)$ \\
\hline Belgium & -0.0095 & $(0.015)$ & -0.0437 & $(0.055)$ \\
\hline Austria & $0.0611^{\star \star *}$ & $(0.027)$ & $-0.1452^{\star \star}$ & $(0.051)$ \\
\hline Switzerland & $0.0418^{\star}$ & $(0.024)$ & -0.1292 & $(0.071)$ \\
\hline Spain & 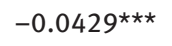 & $(0.012)$ & -0.0843 & $(0.057)$ \\
\hline Italy & -0.0069 & $(0.016)$ & -0.0520 & $(0.052)$ \\
\hline Czech Republic & -0.0168 & $(0.016)$ & -0.0660 & $(0.063)$ \\
\hline Poland & $-0.0701^{\star \star \star}$ & $(0.008)$ & $-0.2865^{\star \star \star}$ & $(0.047)$ \\
\hline N. Obs. & 5,634 & & 1,314 & \\
\hline Pseudo R-squared & 0.1799 & & 0.1149 & \\
\hline
\end{tabular}

Significance: ${ }^{\star \star *}=1 \% ;{ }^{* *}=5 \% ;{ }^{*}=10 \%$

Notes: In the first two columns the outcome variable in the model reported in Table 3.2 is the probability of entering financial distress in Wave 4 given that an individual was not in financial distress in Wave 2. The outcome variable in the model reported in the second two columns is the probability of leaving financial distress in Wave 4 given that an individual was in financial distress in Wave 2. Income, home-ownership, limitation with activities and poor health are relative to Wave 2 .

Source: SHARE Wave 2 release 2.5.0, Wave 4 release 1

The outcome variable in the model reported in the second two columns of Table 3.2 is the probability of leaving financial distress in Wave 4 given that an individual was in financial distress in Wave 2. The sample size is much smaller compared to the previous model (down to 1,314 households), but the protective role of Wave 2 income and home-ownership is confirmed. 


\subsection{The crisis highlights the need the for a wealth buffer in old age}

In this chapter we have shown how wealth holdings of European individuals aged 65 or more were affected by the onset of the great recession, and in particular to what extent the adverse business cycle conditions have increased their financial distress.

In the first part of the paper, we have considered the cross sectional evidence from the most recent wave (2011-12), finding that housing tenure still plays a key role in household portfolios. We have defined a financial distress indicator that signals low liquid wealth for a given income. We have shown that financial distress is linked to some household demographic and socio-economic characteristics, with the leading role played by home-ownership, education and income.

In the second part we have analysed changes in financial distress for those individuals who participated also in a previous wave (2006-7). The comparison of household conditions before and after the great recession shows, as we can expect, a generalised worsening in terms of financial distress in all European countries with only a few exceptions. We find that pre-crisis high per-capita income, home-ownership, education and being married all reduce the risk of falling into financial distress during the crisis.

\section{References}

Angelini, Viola, Brugiavini, Agar, Weber, Guglielmo (2012): “The dynamics of homeownership among the 50+ in Europe". In: Journal of Population Economics (forthcoming).

Christelis, Dimitri, Jappelli, Tullio, Paccagnella, Omar, Weber, Guglielmo (2009): “Income, wealth and financial fragility in Europe”. In: Journal of European Social Policy 19(4), p. 359-376.

Modigliani, Franco (1976): “Life-cycle, individual thrift, and the wealth of nations". American Economic Review 76(3), p. 297-313.

Modigliani, Franco, Brumberg, Richard (1954): "Utility analysis and the consumption function: an interpretation of cross-section data". In: Kurihara, Kenneth (Ed.): PostKeynesian economics. New Brunswick, NJ: Rutgers University Press, p. 388-436. 